iRASD Journal of Economics
Volume 1, Number 2, 2019, Pages $68-81$
$\begin{gathered}\text { Journal Homepage: } \\ \text { IRASD }\end{gathered}$

\title{
Sectorial growth, Exchange rate and Fiscal policy in Developing Economies: The Interlinkages
}

\author{
Snober Fazal ${ }^{1}$, Muhammad Azhar Bhatti ${ }^{2}$, Tusawar Iftikhar Ahmad ${ }^{3}$ \\ ${ }^{1}$ MPhil Scholar, The Islamia University of Bahawalpur, Email: snoberfazal44@yahoo.com \\ ${ }^{2}$ Visiting Lecturer, The Islamia University of Bahawalpur, Email: azhar.bhatti219@gmail.com \\ ${ }^{3}$ Aisstant Professor, The Islamia Univeristy of Bahawalpur, Email: tusawar.iftikhar@iub.edu.pk
}

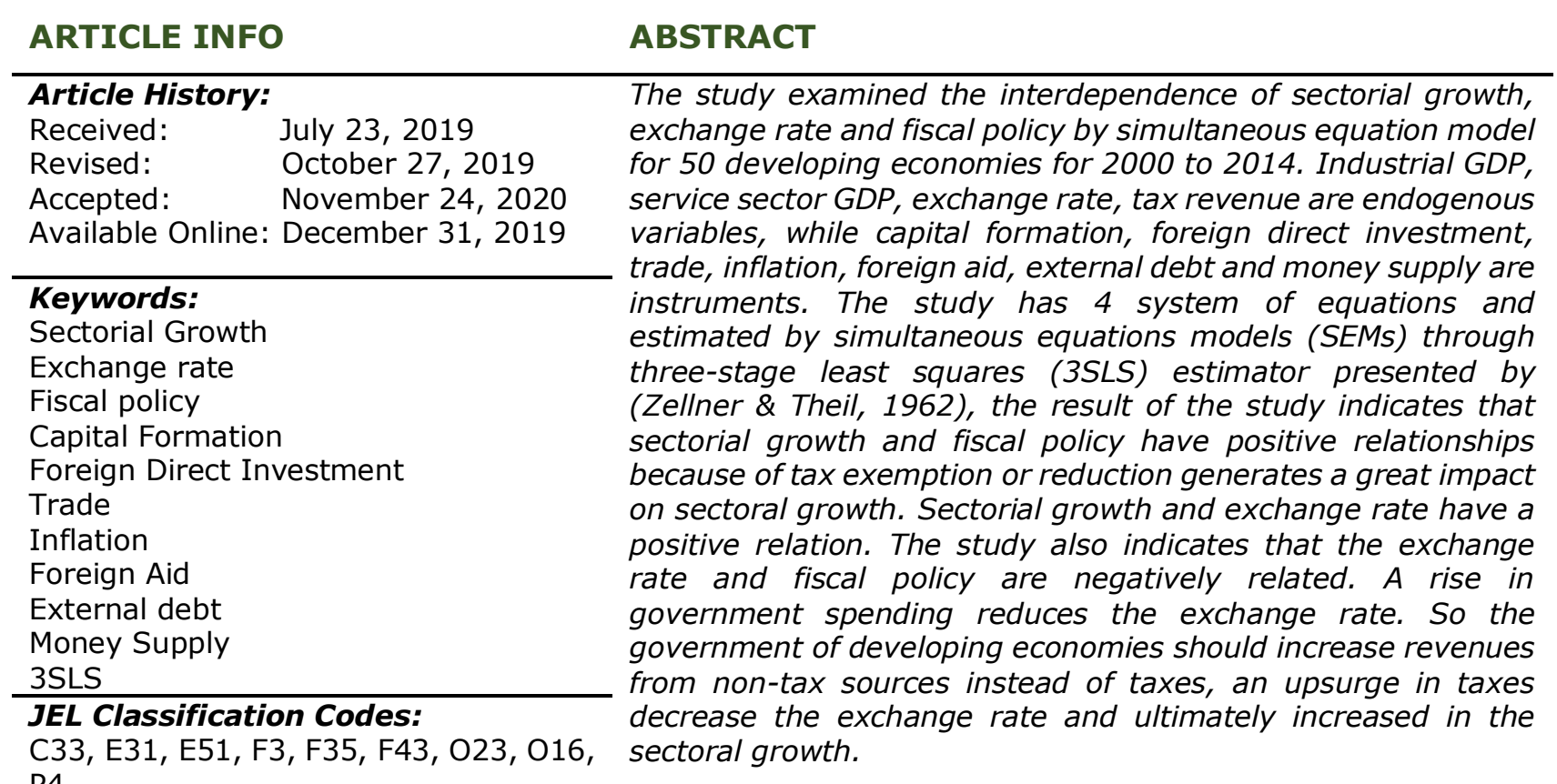
P4

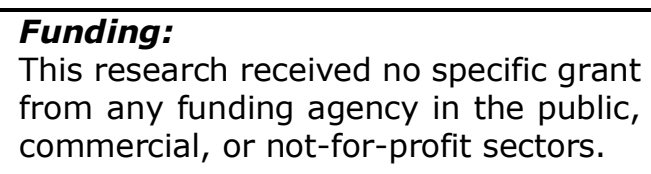

OPEN ACCESS

(C) 2019 The Authors, Published by iRASD. This is an Open Access Article under the Creative Common Attribution Non-Commercial 4.0

Corresponding Author's Email: snoberfazal44@yahoo.com

Citation: Fazal, S., Bhatti, M. A., \& Ahmad, T. I. (2019). Sectorial growth, Exchange rate and Fiscal policy in Developing Economies: The Interlinkages. IRASD Journal of Economics, 1(2), 68-81.

https://doi.org/10.52131/joe.2019.0101.0006

\section{Introduction}

The economy depends on three major sectors which are agriculture, industrial and service sectors. Sectoral growth has a key determinant of the growth of countries because it declines in the poverty rate in many countries due to the accelerated growth. Countries experienced more development and growth due to the industrial sector which enhances the living standard of the people and boosts the national income. Later, the service sector replaced the industrial sector, as income of peoples continually raised they demand more services in entertainment, education, health and other sectors. The service sector produces intangible goods more surely services instead of goods so, those countries whose economies placed around the service sector are measured more progressive than industrial or agricultural economies.

Most of the economies followed the positive and remarkable structure of sectorial transformation in the practice of economic development. According to(Kuznets \& Murphy, 1966), it is identified from different countries that the arrangement in aggregate output from 
the primary sector (agriculture), increase in the secondary sector (industrial) and also in the service sector is the path of economic growth and development. That means the share of the service sector and industrial sector to the GDP is continually rising and have great importance to converge an economy on a sound basis. Technological changes in economic growth are very much necessary because, technological changes were in the manufacturing sector in the process of the industrial revolution as (Cornwall, 1977; Kaldor, 1977) stated that for economic growth, development of this sector is very essential (Verspagen, 2000).

An upsurge in investment level which leads to the rise in the sectoral growth of the economy (Branson, 1986; Buffie, 1986; Van Wijnbergen, 1986)leads to appreciating in the exchange rate, price of capital reduced results increased in the demand level. So, this encourages new investment and increases aggregate demand so an increase in growth increased the exchange rate. Besides this, the rise in the economic activity grows the level of tax revenue which shows the economy grows up in the form of new plant results increased in the tax level.

Fiscal policy is effective in both cases elastic and inelastic exchange rate but it is more effective under the case of fix exchange rate Mundell-Fleming. Policymakers and economists define that rise in the exchange rate has beneficial for trade and growth. The exchange rate enhanced growth level by the expansionist effect which increased in the level of exports more than imports (Bahmani-Oskooee \& Mirzai, 2000). Many countries increase their exchange rate after interdependence as a strategy to increase their production level.

Edwards (1989); (Kamin, 1988) confirmed that both output and output growth decline as exchange rate devaluate. Higher exchange rate decreases the prices of exports that means our exports are cheaper now for a foreign country. So, they demand more exports because they are paying less from before. As the demand for exports increases, industry increases its production and its GDP increases. If the exchange rate appreciated then exporters don't want to exports. But they are not stopping to export because they did not want to lose their old markets and also found new markets (Kemal \& Qadir, 2005) as high exchange rate have a small increase in industrial GDP. And the reduction of exchange rate boosts when the government increases its expenditure (spending). As the spending of government rises it boosts the devaluation of the real exchange rate (Monacelli \& Perotti, 2010).According to John Maynard Keynes decrease and increase of tax revenues and spending (expenditure) of government which affects the level of inflation and money supply and employment with the economic system. In the recession, the government decreased tax level to attract the aggregate demand which increased in disposable income.

Fiscal policy has a great influence on the production level that is based on exported goods. It is a mechanism in which trade balance effects by the spending of government and taxation (Tadele, 2013), it depends on an optimal supply of goods (Baxter, 1995; Mundell, 1963; Obstfeld \& Rogoff, 1995), If an economy wants to promote its industrial sector, it will use tax revenue to promote its industrial sector by new investment in the industrial sector, in mining (petroleum, different gases, water etc.), on manufacturing projects, electricity, construction, water and gas etc. So as more taxes (income of government) will use to increase the production of industry and also the portion of the industrial sector in the country's GDP(Edwards, 1989; Kamin, 1988) confirmed that both output and output growth decline as the exchange rate devaluate ${ }^{1}$.

Macroeconomic policies have an important and significant role, particularly to boosts the export and given the incentives to import exchange rate policies play a vital role see also [Marshal Lerner conditions]. Like interest rate will be raised as government spending increases under a flexible exchange rate that will increase the worth of the home currency by appreciation. According to theoretical and empirical research proves that there exists interdependence between sectoral growth, exchange rate, and tax revenue. By maintaining the level of tax revenue which minimized exchange rate results, ultimately increased economic growth.

\footnotetext{
${ }^{1} \mathrm{~A}$ rise in exchange rate decrease the prices of exports that means our exports are cheaper now for foreign country. So, they demand more exports because they are paying less from before. 


\section{Literature Review}

According to theoretical and empirical literature has explored sectorial growth, exchange rate and fiscal policy and their tools for the world with different functional forms, estimation techniques and data-sets.

Cushman (1983) examined the influence on international trade due to the real exchange rate further which was addition and variation in the study of (Hooper \& Kohlhagen, 1978) framework. The theoretical framework of the supply of export and the pattern of demand forHooper-Kohlhagen used in this study. The findings specify this study could be beneficial with altered estimation techniques, factors and alternatives. Kemal and Qadir (2005) examined exchange rate activities in the long run, also imports and exports in the case of Pakistan. Results indicating that the real exchange rate inversely but significantly affecting exports while positively with the imports.

I. S. Chowdhury (2004)examined the exchange rate regime with important fiscal policy tools that focus on the role of trade openness. This study used the special case of the exchange rate which was the "de facto exchange rate regime" which used as the proxy of the rate of exchange regime. Results indicated that the exchange rate has a significant influence on the fiscal policy and its tools through the interaction of the exchange rate and trade openness. There is a significant association amid the rate of exchange with the import price level in just one country from a number of the country used. Besides this, the association between the exchange rate and export price level (M. T. H. Chowdhury, Bhattacharya, Mallick, \& Ulubaşoğlu, 2016).

Jayasinghe and Tsui (2008)examined the Japanese industrial sector according to exchange rate exposure and industrial sectors returns and their volatilities. The theme of the research was to inspect the instabilities of stock returns and rate of exchange which are the main factors for decisions of investment, hedging and sectorial returns. Further, there were two other stages of exchange rate introduction of sectorial earnings which were (i) how much sensitive volatility of stock profits in terms of the external exchange market and (ii) correlation between the returns of stock and exchange rate variations. The result indicated that the exchange rate's traditional coefficient did not capture fully the whole currency danger which essentially challenged by the firms. When stock return indexes used than what was the validity arguments of exchange rate exposure. Finally on the large scale when the instability of stock returns significantly influenced to the instability of alteration in the exchange rate so the effect of exchange rate shock on stock return conditional volatility might be larger as compared to its volatility.

Monacelli and Perotti (2010) examined the fiscal policy, traded goods and real exchange rate to estimate the activities of GDP and private consumption through the impact of government expenditure (payments) surprise on the level of trade and rate of exchange. Four OECD countries (the United Kingdom, the United States, Canada and Australia) used. The relationship also discussed in four OECD economies which were based on government spending and fiscal policy on the real exchange rate and trade goods (Corsetti \& Müller, 2006; Perotti, 2005, 2007). Results of this study based on the two main reasons. The first exchange rate reduces as the government increases spending and balance of trade deficit especially in the case of the USA and then its effects move to decreases. Secondly, countries including in the study face great effect on consumption as the government increase the expenditures and indicating the definite relation with exchange rate. There are few other studies which debate over the exchange rate movement as (Corsetti \& Dedola, 2005).

Caporale, Ciferri, and Girardi (2011)examined real exchange rate dynamics and fiscal policy shocks. Fiscal shocks that affect the dynamics of the real exchange rate in most economies and monetary tool's importance can be seen. When their small cyclic instabilities were used it increases in the power shocks of demand. This also suggests the underestimating of fiscal conflicts and overestimating the shock of demand which arises the question about the stability of the research of some earlier shreds of evidence for this paper criticize (I. S. Chowdhury, 2004; Roldos \& Hoffmaister, 2001). Chatterjee and Mursagulov (2016) examined the effect of the fiscal policy and real exchange rate, also examined the mechanism which 
concluded the government spending on the infrastructure of the public sector and associated financing policies that effects dynamic exchange rate. Results indicated that intertemporal impact among private consumption, exchange rate and spending of government.

Nawaz (2012)inspected the change in GDP growth along with the variations of the level of the nominal exchange rate. ARDL, the bond test used to check the length as well as the short-run relationship between the real GDP and nominal exchange rate in the case of Pakistan. Depreciation in the level of real exchange rate occurred higher differenced in the output level as maintained by (Dornbusch, 1988). Government spending played an important part in the reduction in the output level in both the long and short run, because of the crowding out and excess of the non-development spending from the total spending of government. Results also indicated that trade had a positive relationship with output level in the short term but had not satisfactory impact in long run.

Lashmi \& Kumar (2012) examined the determinants which affect India's service sector growing sequence of India's service economy and their sub economies. The study indicated that growth in the Indian service sector had more as compare to the other sectors like Indian agriculture or industry sectors. (Born, Juessen, \& Müller, 2013) examined the exchange rate and fiscal multipliers whose contribution was twofold. First of all conformation of the regime of the exchange rate and fiscal spread was checked, which depends on the special data set of the OECD member countries and secondly it was investigated whether the time series had sufficient evidence to recognized on the basis on the New Keynesian small open economy. The outcomes specified that under the fixed exchange system the multiplier had significant and larger impact and also showed that New Keynesian model showed significant and satisfactory results.

Singh (2014) examined the Indian service sector which was determining the upcoming retail industry of India. Results indicated that the retail industry of the Indian economy contributing almost $14 \%$ to $15 \%$ in GDP for the economic growth of India. FDI had an impact with $100 \%$ with the only brand and $51 \%$ with multiple brands invested in different sectors, which gives the attention to other studies to improve the business in this sector for the country's improvement. In India, this is making the future business as well.(Šimáková \& Stavárek, 2014) examined both short and long-run association amid trades flows due to change in the rate of exchange. In this study, it is defined that Czech currency depreciation benefits industrial trade and also superior consideration were on the J curve impacts on different groups empirically. Results indicated that a new approach for testing the relationship in short and also in long run effects of currency depreciation was theoretical assumptions agreement.

Akevy and Gifter (2014) examined the exchange rate exposure on both firm and industrial level in the case of Turkey. Exchange rate of each firm calculated by openness by GDP (Dominguez \& Tesar, 2006). Results indicated that macroeconomic variables played an important role in for chemical industry and also for the metal sectors. Results also showed that not bigger firms faced the exchange rate exposure risk for Turkish sectors.

Pylak and Majerek (2015) examined the impact on the service sectors on the establishment of companies in Poland from different industries. First of all this study gave new tools for revealing new business creativity in Polish. This study used three hypotheses to achieve this aim. Making of new firms was very complicated and difficult under some rules and conditions this process is too big which created the diversification. The most interesting part is that 8 service sector companies and one construction company followed these rules and no rule followed the manufacturing sector. This means that the service sector influenced the rate of growth as compared to other sectors. According to the above results, one hypothesis was that their need to enhance the sectors of manufacturing and agriculture and building sectors should be in a small number of processes.

\section{Methodology}

This analysis is based on interdependence between Sectorial growth, exchange rate, and fiscal policy. The model system of equations contains four endogenous variables with the 
number of exogenous variables for developing countries. Hence the functional form is shown below.

\subsection{Simultaneous Equations Model}

SEM includes endogenous and exogenous variables. Endogenous variables are those variables which are resolute from the system of equations (Pindyck \& Rubinfeld, 1997; Wooldridge, 1996, 2009) with other supporting variables. It relates with the residuals of the model which create the problem of endogeneity and violate the basic assumption of Ordinary Least Square (OLS) and Gauss Markov (Wooldridge, 2009) which represent in the equations 1 and $2, Z$ are pure exogenous variables and $Y$ and $X$ are endogenous variables. And the Exogenous variables are determined from outside of the model.

$Y_{i t}=\alpha_{11}+\alpha_{12} X_{, i t}+Z_{1, i t}++Z_{2, i t}+\epsilon_{i t}$

$X_{i t}=\alpha_{11}+\alpha_{12} Y_{, i t}+Z_{3, i t}++Z_{4, i t}+\epsilon_{i t}$

\subsection{Three-Stage Least Square}

The technique of 3SLS (Three-Stage Least Squares) was presented by (Theil\& Zellner, 1962). This procedure showed the special situation of GMM with multi equations in which in all equations the set of instrument variables are same. When all regressors are prearranged, then 3SLS eases to SUR (seemingly unrelated regressions). Therefore it may also be seen as a mixture of 2SLS (two-stage least squares) through SUR(Pindyck \& Rubinfeld, 1997; Wooldridge, 1996).

The most summarizing manner to symbolize a structure of equation for 3SLS necessitate thinking of the single-equation and connected data as being stack. The system could then be formulated is general form as:

$\left[\left(X^{\prime} Z\right)\left(\sum_{i=1}^{n} Z i^{\prime} \Omega Z 1\right)-1\left(Z^{\prime} X\right)\right]-1=\left[X^{\prime} Z\left(Z^{\prime}(I N \Omega) Z\right)-1 Z^{\prime} X\right]-1$

3SLS is seemed to be the best methodology if we go for a bidirectional relationship among variables. Simultaneous equations describe our statement of the problem in appropriate manners. The assumptions of 3SLS are the best fit for the stated problem of the current study. Through 3 sls we can estimate the relationship among more than one variable or they cause each other or not.

\subsection{Endogeneity}

While in the SEM endogeneity problem occur when independent variables are linked with residuals which is due to one and more than more endogenous variables are in the system.

$E\left(X_{j} U\right) \neq 0, \quad$ for some $\mathrm{j}=1, \ldots \ldots \ldots \ldots . ., \mathrm{k}$

There is a problem of endogeneity. OLS or GLS will be unpredictable for $\mathrm{N} \rightarrow \infty$ and T fixed, both for fixed effect and random effect. The endogeneity of the exogenous variables is a severe issue in econometrics. This problem means that the association independent variables and residuals. This issue may be due to the exclusion of suitable variables, selfselection, sample selectivity or measurement error. Endogeneity reasons discrepancy of the typical OLS evaluations and needs instrumental variable (IV) approaches like two-stage least squares (2SLS) or (3SLS) three-stage least square to attain consistent parameter estimates.

\subsection{Regressors Endogeneity test (Durbin-Wu-Hausman test)}

The Durbin-Wu-Hausman Test known also the regressor endogeneity test. If the regressor is explained by the instruments in the model known endogenous, whereas the variables which are not explained through instruments are exogenous.

$H_{t}={ }_{t}^{1}(\beta)^{\prime} Z W_{t}^{-1} Z^{\prime} u(\beta)^{\prime} Z W_{t}^{-1} Z^{\prime} u(\beta)^{\prime}$ 
Where $\hat{\beta}$ is the parameter which evaluates from the unique valuation by using weights $W_{t}$ and $\beta$ are the estimated from the test equation estimation using $Z$ instrument's augmented by the variables which are being tested and $W_{t}$ is the weighted matrix from the secondary estimation?

So the Hausman test used to determine whether the explanatory variables in regression are suffering from endogeneity or not.

\section{Hypothesis}

$H_{o}=\delta_{1}=0$ Endogeneity does not exist

$H_{a}=\delta_{1} \neq 0$ Endogeneity exists

\subsection{Theoretical Model and Construction of Variables}

IGDP $=f(E X R, T A X, C F, F D I, S G D P)$

$E X R=f(I G D P, T A X, I N F, F A I D, S G D P)$

$T A X=f(I G D P, E X R, E D E B T, M 2, S G D P)$

$\mathrm{SGDP}=\mathrm{f}(\mathrm{IGDP}, \mathrm{EXR}, \mathrm{TAX}, \mathrm{TRADE}, \mathrm{FDI})$

The description of the variables is given in Table 1

\section{Table 1}

Description of Variables

\begin{tabular}{lll}
\hline Variables & Explanation & Unit \\
IGDP & Industrial GDP & $\%$ of GDP \\
EXR & Exchange Rate & LCU per US $\$$, period average \\
TAX & Tax Revenue & $\%$ of GDP \\
SGDP & Service sector GDP & $\%$ of GDP \\
EDEBT & External Debt & $\%$ of GNI \\
CF & Capital Formation & $\%$ of GDP \\
FAID & Foreign Aid & current US\$ \\
M2 & Money Supply & $\%$ of GDP \\
TRADE & Trade & $\%$ of GDP \\
FDI & Foreign Direct Investment & BOP, current US\$ \\
INF & Inflation & Annual $\%$
\end{tabular}

Data set consists of 50 developing countries ${ }^{2}$ from 2000 to 2014. It has been taken from world development indicators (World Bank, 2015a), the organization for economic cooperation and development (OECD, 2015). The missing values have been adjusted by taking an average of variables. The sample of developing nations is constructed on the accessibility of data.

${ }^{2}$ Armenia, Algeria, Azerbaijan, Botswana, Bangladesh, Burundi, Bhutan, Benin, Bolivia, Cameroon, Cambodia, Chad, China, Comoros, Egypt,Fiji, Georgia, Ghana, Iran, Indonesia, Jordan, Kenya, Lao,PDR, Kazakhstan, Kyrgyz Republic, Mongolia, Malaysia, Mexico, Moldova, Niger, Nepal, Pakistan, Philippines, Sri Lanka, Swaziland, South Africa, Togo, Tajikistan, Thailand, Tonga, Ukraine, Uzbekistan, Vanuatu, Albania, Tanzania, Uganda, Mozambique, Gabon, Grenada and Paraguay. 


\subsection{Visualization Analysis}
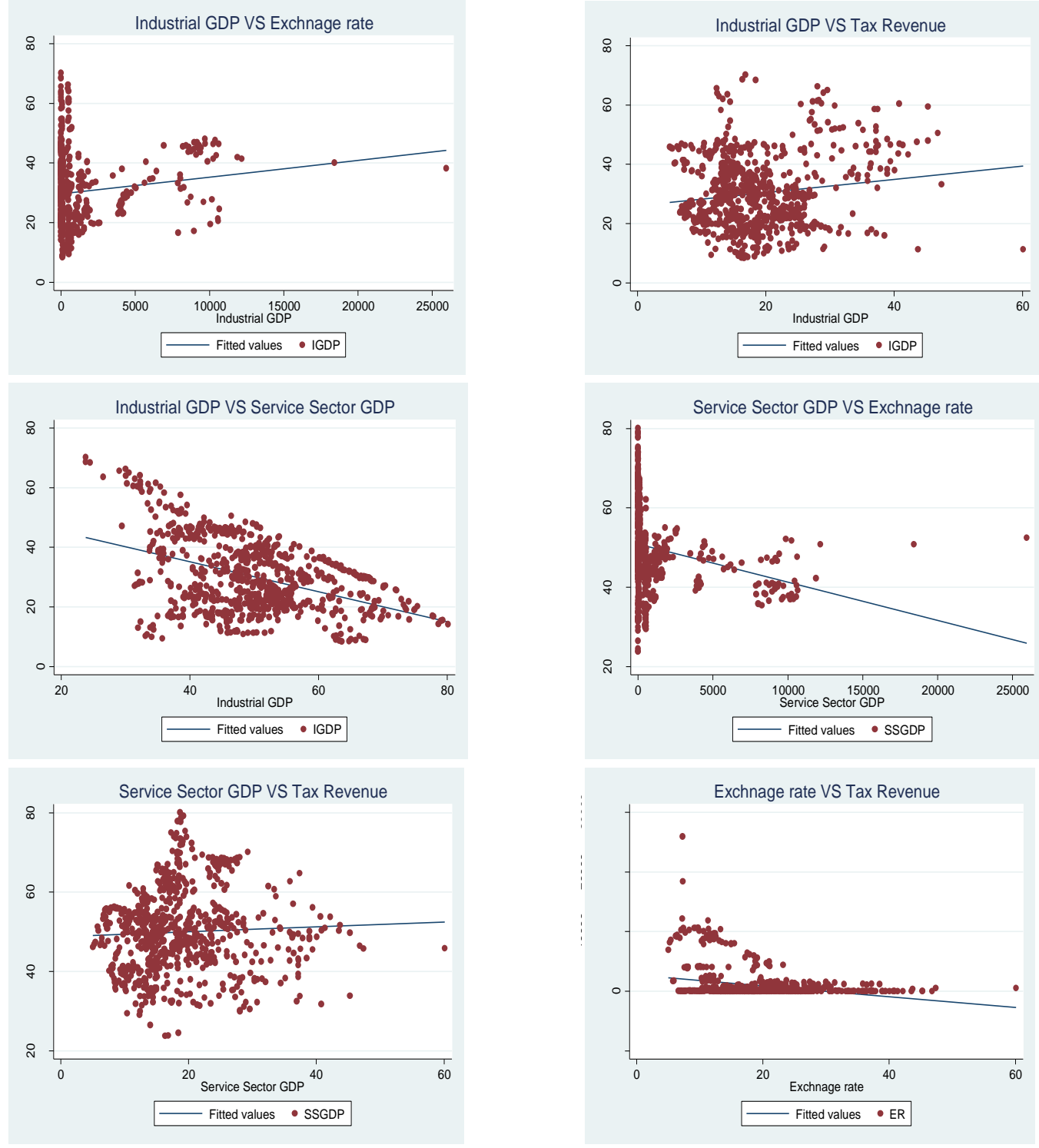

According to visualization analysis which shows the same relationship among them which discuss in the results section.

\subsection{Econometrics Model Specification}

The econometric expression of interdependence among Sectorial growth (we use two sectors industrial sector and service sector), exchange rate and fiscal policy for panel data are shown in equations $6,7,8$ and 9 respectively.

$$
\begin{aligned}
& I G D P=\alpha_{o}+\alpha_{1} E X R_{i t}+\alpha_{2} T A X_{i t}+\alpha_{3} C F_{i t}+\alpha_{4} F D I_{i t}+\alpha_{5} S G D P_{i t}+\epsilon_{i t} \\
& S G D P=\delta_{o}+\delta_{1} I G D P_{i t}+\delta_{2} E X R_{i t}+\delta_{3} T A X_{i t}+\delta_{4} T R A D E_{i t}+\delta_{5} F D I_{i t}+\epsilon_{i t} \\
& E X R=\gamma_{o}+\gamma_{1} I G D P_{i t}+\gamma_{2} T A X_{i t}+\gamma_{3} I N F_{i t}+\gamma_{4} F A_{i t}+\gamma_{5} S G D P_{i t}+\epsilon_{i t} \\
& T A X=\beta_{o}+\beta_{1} I G D P_{i t}+\beta_{2} E X R_{i t}+\beta_{3} E D E B T_{i t}+\beta_{4} M 2_{i t}+\beta_{15} S G D P_{i t}+\epsilon_{i t}
\end{aligned}
$$

In the above equations IGDP, SGDP, EXR, TAX are endogenous variables, while CF, FDI, TRADE, INF, FA, EDEBT, and $M 2$ are instruments and $i$ is for each nation and $t$ is for time series. 


\section{Results and Discussion}

3SLS econometrics technique is used to estimate the equations. Descriptive statistics are shown in table 2. Endogeneity outcomes are represented in table 3 and the estimation results are revealed in Table 4.

Table 2

Descriptive statistics of the variables

\begin{tabular}{lllll}
\hline Variables & Mean & SD & Minimum & Maximum \\
ER & 997.67 & 2507.04 & .54 & 25941.66 \\
TR & 18.63 & 7.75 & 4.99 & 60.09 \\
GFCF & 23.98 & 8.71 & 2.78 & 68.02 \\
IGDP & 30.16 & 11.96 & 8.42 & 70.22 \\
INF & 6.47 & 5.86 & -18.10 & 60.6 \\
FA & $5.58 \mathrm{e}+08$ & $6.69 \mathrm{e}+08$ & $-9.60 \mathrm{e}+08$ & $5.51 \mathrm{e}+09$ \\
M2 & 47.82 & 33.19 & 7.21 & 193.09 \\
SGDP & 49.90 & 10.13 & 23.78 & 80.12 \\
TRADE & 80.72 & 33.90 & 20.96 & 220.40 \\
EDEBT & 48.49 & 33.02 & 1.25 & 187.05 \\
FDI & $5.09 \mathrm{e}+09$ & $2.50 \mathrm{e}+10$ & 31593.78 & $2.91 \mathrm{e}+11$ \\
\hline
\end{tabular}

\subsection{Durbin-Wu-Hausman Test}

\section{Table 3}

Hausman test

$\begin{array}{ll}\text { Durbin Hausman } & \text { Prob>chi2 } \\ & 0.0000\end{array}$

Table 4

Results of SEM for Developing countries

\begin{tabular}{|c|c|c|c|c|c|c|c|c|}
\hline \multirow{3}{*}{$\begin{array}{l}\text { Dependent } \\
\text { variable } \\
\text { Variables }\end{array}$} & \multicolumn{2}{|c|}{ Industrial GDP } & \multicolumn{2}{|c|}{ Service sector GDP } & \multicolumn{2}{|c|}{ Exchange rate } & \multicolumn{2}{|c|}{ Tax revenue } \\
\hline & Coeff. & Prob & Coeff. & Prob & Coeff. & Prob & Coeff. & Prob \\
\hline & $-34.311 * * *$ & 0.000 & $-41.667 * * *$ & 0.000 & $11807.59 *$ & 0.000 & $6.553 *$ & 0.005 \\
\hline IGDP & & & $-1.412 * * *$ & 0.000 & $76.28 *$ & 0.000 & $.173 *$ & 0.000 \\
\hline EXR & $.003 * * *$ & 0.000 & $.004 * * *$ & 0.000 & & & $-.001 *$ & 0.000 \\
\hline TAX & $2.987 * * *$ & 0.000 & $3.637 *$ & 0.000 & $-535.10 *$ & 0.000 & & \\
\hline $\mathrm{CF}$ & .002 & 0.791 & & & & & & \\
\hline FDI & $2.009 *$ & 0.000 & $3.088^{*}$ & 0.000 & & & & \\
\hline FA & & & & & $-254.90 *$ & 0.000 & & \\
\hline SGDP & $-.699 * * *$ & 0.000 & & & $34.61 *$ & 0.001 & $.140 *$ & 0.000 \\
\hline TRADE & & & $.009 *$ & 0.050 & & & & \\
\hline & & & & & $26.82 *$ & 0.000 & & \\
\hline EDEBT & & & & & & & $.0125 *$ & 0.002 \\
\hline M2 & & & & & & & $.015^{*}$ & 0.002 \\
\hline \multicolumn{9}{|c|}{ Model Diagnostics } \\
\hline$\overline{\mathrm{R}^{2}}$ & -2.4351 & & -6.0759 & & -1.6099 & & 0.0475 & \\
\hline $\begin{array}{l}\text { Variable } \\
\text { [IGDP] EXR }\end{array}$ & $\begin{array}{l}\operatorname{chi2}(1) \\
53.75\end{array}$ & $\begin{array}{l}\text { Prob. } \\
0.000\end{array}$ & $\operatorname{chi2}(1)$ & Prob & $\operatorname{chi2}(1)$ & Prob. & $\operatorname{chi2}(1)$ & Prob. \\
\hline [IGDP]TAX & 239.47 & 0.000 & & & & & & \\
\hline [IGDP]SGDP & 609.86 & 0.000 & & & & & & \\
\hline [SGDP]IGDP & & & 514.30 & 0.000 & & & & \\
\hline [SGDP]EXR & & & 29.58 & 0.000 & & & & \\
\hline [SGDP]TAX & & & 147.68 & 0.000 & & & & \\
\hline [EXR]SGDP & & & & & 10.49 & 0.001 & & \\
\hline [EXR]TAX & & & & & 155.74 & 0.000 & & \\
\hline [EXR]IGDP & & & & & 38.59 & 0.000 & & \\
\hline$[$ TAX]IGDP & & & & & & & 18.57 & 0.000 \\
\hline$[T A X]$ EXR & & & & & & & 20.71 & 0.000 \\
\hline [TAX]SGDP & & & & & & & 21.23 & 0.000 \\
\hline
\end{tabular}

Number of observations $=731$

$* 10 \%$ level of significance $\quad * * 5 \%$ level of significance $* * * 1 \%$ level of significance 
According to table 4 Prob value is fewer than $5 \%$ which means we reject the null hypothesis which means endogeneity exists in a model so we used instruments to remove the endogeneity problem.

\subsection{Result for Asian Economies of Three-stage Least Square Method}

This section shows the result of the simultaneous equations of $10,11,12$ and 13 which is estimated by the 3SLS econometrics technique because theoretically there exists the endogeneity in the model and empirically it is confirmed from the Wu-Hausman test.

\subsubsection{Results for Industrial Sector Growth}

The finding explored that exchange rate has an optimistic impact on industrial GDP. This collaboration can be both positive and negative. The debate also exists which defines that domestic production depends on total demand and supply. If depreciation increases total demand (because of an increase in net export) more than the reduction in aggregate supply (as the rise in the input cost of imports), this condition will be called an expansionist effect (Bahmani-Oskooee \& Mirzai, 2000). Many countries increase their exchange rate after interdependence as a strategy to increase their production level. Policymakers and economists define that rise in the exchange rate has beneficial help for trade. Edwards (1989); (Kamin, 1988) modify the study of Cooper confirmed that both output and output growth decline as the exchange rate devaluate. An upsurge in the exchange rate decreases the prices of exports that means our exports are cheaper now for a foreign country. So, they demand more exports because they are paying less from before. As the demand for exports increases, industry increases its production and its GDP increases.

Tax revenue shows a positive impact on industrial GDP. Fiscal policy has a great influence on the production level that is based on exported goods. It is a mechanism in which trade balance effects by the spending of government and taxation. Industry value added to GDP with tax revenue is a statistically significant sign in the short and long run (Tadele, 2013). If an economy wants to promote its industrial sector, it will use tax revenue to promote its industrial sector by new investment in the industrial sector, in mining (petroleum, different gases, water etc.), on manufacturing projects, electricity, construction, water and gas etc. So as more taxes (income of government) will use to grow the production of industry and also the portion of the industrial sector in the country's GDP.

A rise in the FDI (foreign direct investment) showed growth in industrial GDP. There is also some empirical work that explains the significant role of inward FDI in emerging states that gives economic growth by its involvement in technology transfers, boost managerial and organized skills and human resource see also (Aitken \& Harrison, 1999; Barro, 1990; Blomstrom \& Kokko, 1994; Van Wijnbergen, 1986; Zhang, 2001). An optimistic connection amid FDI and IGDP proves when FDI inflows, it increases the host country's production and GDP of industry and also the economic growth of that country.

The service sector negatively affecting industrial GDP because IGDP is sacrificing or giving way to rise in the service sector. Service sector and industrial sector influence each other to grow. The relation among the service sector and the industrial sector had transformed with time but they have a significant long-run relationship as demand for services derives from the industry. According to the above results, they indicate the negative effect of an increase in services it may be due to the inefficient services in industry or fewer services are working in the industrial sector and more are involved in education, health care, in banks, transports are in personal services etc.

According to model diagnostics, $\mathrm{R}$ square value is negative ${ }^{3}$ and the wald test confirms that the Exchange rate has a significant impact on industrial GDP, taxes have a significant impact on IGDP and SGDP have a significant impact on IGDP.

\footnotetext{
${ }^{3}$ However, the R2 is negative. According to Lim, Griffiths and Hill (2008: example 312) the identity SST = SSR + SSE does not hold, while using generalized least square method, 2SLS, 3SLS and SUR, so the value
} 


\subsubsection{Results for Service Sector Growth}

A rise in the GDP of the service sector is resulting in a reduction in the industrial sector. This is primarily due to the increasing portion of the service sector which have great importance in most emerging and industrialized nations(Mitra, 2013). An increase in the industrial GDP will reduce the service sector's GDP because the service sector is sacrificing or giving way to rise in the industrial sector. It is maybe due to the low wage system in the industrial sector. There are two ways when the service sector expands and benefits "the industrial sector" (a) it enables better "division of labour" and specialization (Francois, 1990; Jones \& Kierzkowski, 1988) and (b) cost of industrial production service inputs takedown.

The exchange rate will raise the service sector GDP. There is no doubt that services are traded. In general, we expect the home currency to appreciate, in case of any traded product including services, rise in the imports which are now cheaper and in foreign market reduction their competent authority as their exported products become comparatively more costly. Now we can import services at fewer prices which increase our services GDP.

Tax revenue positive effects service sector GDP. Tax policy of tax exemption or reduction is also used for generation employment. Mostly government faces budget deficit because it increases its expenditure due to increasing the consumption and investment for the employment benefits (Leeatham, 2000). As an economy continue its development structure then more workers will start to move from the agriculture sector (secondary) to the service and industrial sector (Cypher \& Dietz, 2004). As any sector of the economy grows the tax level will increase.

As trade increases then the GDP of the service sector increases because trade motivates the service sector to increase. FDI has an optimistic influence on the service sector GDP. In emerging countries, FDI rises economic growth because of technology spillovers but not in developed countries. FDI inflows significantly improved real GDP in the long run and later economic growth (Johnson, 2006). So, the inflows of FDI impact positively on the increase in the service sector's GDP.

According to model diagnostics, the Wald test is used to find out that explanatory variables are significantly used in a model. In the above table 4, Industrial GDP has a significant influence on service sector GDP, secondly, the exchange rate has a significant influence on SGDP and finally, taxes have a significant impact on SGDP.

\subsubsection{Results for Exchange rate}

Industrial GDP positively affects investment. As an increase in new investment(Branson, 1986; Van Wijnbergen, 1986 \& Buffie, 1986) in developing countries, new investment based on imported capital so as exchange rate appreciated the prices of capital reduces and their demand increases. This encourages new investment and increases aggregate demand so rise an increase in IGDP positively related to the exchange rate because a rise in IGDP is due to increase the demand for goods that increase the portion of the industrial sector. It will move the economy to development and its currency to appreciate and also exchange rate to increase.

Tax revenue negatively affecting the exchange rate ${ }^{4}$. Tax revenue and exchange rate are negatively related may be due to inflation, so the government wishes to reduce aggregate demand, it will increase the taxes and decrease the disposable income, both inflation and GDP will decrease that will reduce the demand of currency and exchange rate too. It is called the contractionary fiscal policy.

of $\mathrm{R}^{2}$ would be negative. This only showed the goodness of fit is not appropriate in this context and should be ignored.

${ }^{4}$ Over the last 30 years increase the budget deficit of US, is follow by the perfection in current account balance and a depreciation in exchange rate [Kim and Roubini (2009)]. 
Rise in inflation increasing the exchange rate. Inflation closely relates to interest rate, which also influences the exchange rates. By economist, if the inflation rate is high in a country generally but if it is still lower than that of other nations the comparative value of its currency can be greater than that of the other country's currency. It is the condition when an economy facing a high aggregate demand for goods and currency so that appreciates the currency and exchange rate also to increase.

Foreign aid negatively affecting the exchange rate because domestic savings are not sufficient and enough to afford the resources to meet desired levels of investment. Second, the earnings of exports are not sufficient for the finance of importation of capital goods. As a result, such developing countries make constrained in their talent to achieve their goal of growth rates. In this approach, foreign aid is the contribution of financial investment, capital goods and including imports(Arhenful, 2013).

Service sector GDP and exchange rate have a positive relation. It displays that services increasing the growth of economic sectors in emerging nations and increasing the value of home currency in terms of foreign currency so the exchange rate will increase. (Hassan \& Holmes, 2013; Lopez, Fajnzylber, Calderon, \& Acosta, 2007)an institute that in developing countries rise in the remittances effects in higher spending which concludes a rise in the price of non-tradable. So, it will appreciate the exchange rate level.

The Wald Chi-Squared test also called a Wald test is used to determine the independent variables are significant in the model. According to the result of table 4 , the Service sector GDP has a significant outcome on the exchange rate, taxes have also a significant impact on the exchange rate and finally, industrial GDP has a significant influence on the exchange rate.

\subsubsection{Results for Industrial Tax Revenue}

A rise in economic activity leads to an increase in tax revenues more rapidly than before. A positive relationship between industrial GDP and tax revenue shows when the economy grows up in the form of a new plant or as any sector of the economy increases its production it has to pay more tax on it.

The exchange rate is reducing tax revenue. The decline of exchange rate boosts when the government increases its expenditure (spending). As government raise its spending it boosts the depreciation of the real exchange rate. The adverse connection between these two variables is described in (Monacelli \& Perotti, 2010).

External debt is used to get the sustained growth of the economy, which is by using the given domestic resources is not feasible. This situation of high indebtedness dampen investment and adversely influence growth as to repay this debt future higher taxes are expected. Pakistan Governments have virtually no means of repaying debt other than through future taxation (Ali, Waqas, Asghar, Mustafa, \& Kalroo, 2014).

The government of the respective central bank regulate the tools of monetary(money supply) and fiscal (tax/revenue) policies in an economy. If the government facing a budget deficit it will reduce its expenditures and increase its revenues by taxes. Tax revenues and money supply are positively related are discussed in (Musa, Usman, \& Zoramawa, 2014).

Service sector GDP increasing the revenues of taxes ${ }^{5}$. As the share of the service sector increases as transport, financial, government and personal services like health, education and real estate services. The rise in the service sector is also involved in national compiler noted duties of imports and dispensaries and bank service charges

Industrial GDP has a significant influence on taxes, the exchange rate has a significant effect on taxes and finally, service sector GDP has a significant influence on taxes.

\footnotetext{
${ }^{5}$ In 1994 the government of India introduced the service tax of 5\%in the Finance Act only on the services. With modest establishment, the portion is increased every year by either bringing new services under increasing tax rate or the tax net [CA Ayush Agarwal (2012)].
} 


\section{Conclusion}

It is concluded that there exists the interdependence between the sectoral growth, exchange rate and fiscal policy of 50 emerging countries over the period of 2000 to 2015. Sectoral growth increased the level of fiscal policy and exchange rate (Cottani, Khan \& Cavallo 1990; Ghura \& Grennes, 1993). The exchange rate has negatively related to fiscal policy but has a positive relation with sectoral growth. Tax revenue shows that fiscal policy is positively related to sectorial growth but has an adverse influence on the exchange rate that is also discussed in (Monacelli \& Perotti, 2010).

Sectorial growth and fiscal policy have a positive relationship with each other because tax exemption or reduction generates a great impact on sectoral growth. Fiscal policy effect goods and services. Usually, the government faces a budget deficit as it increases its expenditure to help the service sector employment by encouraging investment and consumption (Leeatham, 2000). The government uses its income for new investment and it increases industrial production. So, the fiscal policy has an optimistic effect on sectoral growth.

Sectorial growth and exchange rate have a positive relation with sectorial growth. Fiscal policy and exchange rate are negatively associated. The exchange rate depreciates as the government increases its expenditure (spending). The negative relationship between these two is described in (Monacelli \& Perotti, 2010). The first impression is that one may have is that devaluation of domestic currency should every time lead to enhancement of the balance of payments in a country. To increase economic productivity, fiscal policy has a very important role in the allocation of money, men and mineral productive resources. All those productive resources utilized and distributed which make the maximum influence on employment, income and national output. To changes in employment level and output, there is an extensive consensus that automatic stabilizers deviations in taxes and transfers that happen automatically have an important role to play (Baggs, Beaulieu, \& Fung, 2009). If the economy is facing inflation and wants to decrease aggregate demand to control the situation so the government applies a contractionary fiscal policy that will increase the taxes and decrease the disposable income. It will gave the results by decrease in demand for goods and currency that will depreciate the currency. In this situation, the supply of goods increases as compare to demand as exchange rate is now its lower condition so this supply will export in international markets.

The government has greater control over its revenue, by using its authority of taxation. The local and federal governments can increase their revenues by increasing taxes. If these revenues use in new investment or productive projects like industries it may increase the GDP of that sector. If all the collected revenues from the taxation spend properly then it will find its way through government expenditures to total demand. The government of developing economies should increase revenues from non-tax sources instead of taxes, an increase in taxes decrease the exchange rate and ultimately increased in the sectoral growth.

\section{Conflict of Interests/Disclosures}

The authors declared no potential conflicts of interest w.r.t the research, authorship and/or publication of this article.

\section{References}

Aitken, B. J., \& Harrison, A. E. (1999). Do domestic firms benefit from direct foreign investment? Evidence from Venezuela. American economic review, 89(3), 605-618.

Ali, S., Waqas, H., Asghar, M., Mustafa, M. Q., \& Kalroo, R. A. (2014). Analysis of Financial Development and Economic Growth in Pakistan.

Arhenful, P. (2013). The Effect of Foreign Aid on Real Exchange Rate in Ghana. Advances in Management and Applied Economics, 3(5), 151.

Baggs, J., Beaulieu, E., \& Fung, L. (2009). Firm survival, performance, and the exchange rate. Canadian Journal of Economics/Revue canadienne d'économique, 42(2), 393-421.

Bahmani-Oskooee, M., \& Mirzai, A. (2000). Real and nominal effective exchange rates for developing countries: 1973: 1-1997: 3. Applied Economics, 32(4), 411-428. 
Barro, R. J. (1990). Government spending in a simple model of endogenous growth. Journal of political economy, 98(5, Part 2), S103-S125.

Baxter, M. (1995). International trade and business cycles. Handbook of international economics, 3, 1801-1864.

Blomstrom, M., \& Kokko, A. (1994). Home country effects of foreign direct investment: evidence from Sweden. Retrieved from

Born, B., Juessen, F., \& Müller, G. J. (2013). Exchange rate regimes and fiscal multipliers. Journal of Economic Dynamics and Control, 37(2), 446-465.

Branson, W. H. (1986). Stabilization, stagflation, and investment incentives: The case of Kenya, 1979-1980. In Economic adjustment and exchange rates in developing countries (pp. 267-294): University of Chicago Press.

Buffie, E. F. (1986). Devaluation, investment and growth in LDCs. Journal of Development Economics, 20(2), 361-379.

Caporale, G. M., Ciferri, D., \& Girardi, A. (2011). Fiscal shocks and real exchange rate dynamics: Some evidence for Latin America. Journal of International Money and Finance, 30(5), 709-723.

Chatterjee, S., \& Mursagulov, A. (2016). Fiscal policy and the real exchange rate. Macroeconomic Dynamics, 20(7), 1742-1770.

Chowdhury, I. S. (2004). Sources of exchange rate fluctuations: empirical evidence from six emerging market countries. Applied Financial Economics, 14(10), 697-705.

Chowdhury, M. T. H., Bhattacharya, P. S., Mallick, D., \& Ulubaşoğlu, M. A. (2016). Exchange rate regimes and fiscal discipline: The role of trade openness. International Review of Economics \& Finance, 45, 106-128.

Cornwall, J. (1977). Modern capitalism: its growth and transformation: Martin Robertson.

Corsetti, G., \& Dedola, L. (2005). A macroeconomic model of international price discrimination. Journal of International Economics, 67(1), 129-155.

Corsetti, G., \& Müller, G. J. (2006). Budget deficits and current accounts: Openness and fiscal persistence. Economic Policy, 21(48), 597-638.

Cottani, J. A., Cavallo, D. F., \& Khan, M. S. (1990). Real exchange rate behavior and economic performance in LDCs. Economic Development and Cultural Change, 39(1), 61-76.

Cushman, D. O. (1983). The effects of real exchange rate risk on international trade. Journal of International Economics, 15(1-2), 45-63.

Cypher, J., \& Dietz, J. (2004). The Process of Economic Growth. London and New York: Routledge.

Dominguez, K. M., \& Tesar, L. L. (2006). Exchange rate exposure. Journal of International Economics, 68(1), 188-218.

Dornbusch, R. (1988). Real exchange rates and macroeconomics: a selective survey. In: National Bureau of Economic Research Cambridge, Mass., USA.

Edwards, S. (1989). Exchange controls, devaluations, and real exchange rates: the Latin American experience. Economic Development and Cultural Change, 37(3), 457-494.

Francois, J. F. (1990). Producer services, scale, and the division of labor. Oxford Economic Papers, 42(4), 715-729.

Ghura, D., \& Grennes, T. J. (1993). The real exchange rate and macroeconomic performance in Sub-Saharan Africa. Journal of Development Economics, 42(1), 155-174.

Hassan, G. M., \& Holmes, M. J. (2013). Remittances and the real effective exchange rate. Applied Economics, 45(35), 4959-4970.

Hoffmaister, A. W., \& Roldos, J. E. (2001). The sources of macroeconomic fluctuations in developing countries: Brazil and Korea. Journal of Macroeconomics, 23(2), 213-239.

Hooper, P., \& Kohlhagen, S. W. (1978). The effect of exchange rate uncertainty on the prices and volume of international trade. Journal of International Economics, 8(4), 483-511.

Jayasinghe, P., \& Tsui, A. K. (2008). Exchange rate exposure of sectoral returns and volatilities: Evidence from Japanese industrial sectors. Japan and the World Economy, 20(4), 639-660.

Johnson, A. (2006). The effects of FDI inflows on host country economic growth. The Royal Institute of technology. Centre of Excellence for Studies in Science and Innovation http://www. infra. kth. se/cesis/research/publications/working papers.

Jones, R., \& Kierzkowski, H. (1988). The Role of Services in Production and International Trade: A Theoretical Framework

UniversityofRochesterGCenterforEconomicResearch (RCER). 
Kaldor, N. (1977). Capitalism and industrial development: some lessons from Britain's experience. Cambridge Journal of Economics, 1(2), 193-204.

Kamin, S. B. (1988). Devaluation, external balance, and macroeconomic performance: a look at the numbers: International Finance Section, Department of Economics, Princeton University.

Kemal, M. A., \& Qadir, U. (2005). Real exchange rate, exports, and imports movements: A trivariate analysis. The Pakistan Development Review, 177-195.

Kuznets, S., \& Murphy, J. T. (1966). Modern economic growth: Rate, structure, and spread (Vol. 2): Yale University Press New Haven.

Lashmi, P., \& Kumar, S. (2012). A Study of Factors Affecting the India's Service Sector: An Econometric Analysis. International Journal of Business Management \& Economic Research, 3(2).

Leeatham, P. (2000). Monetary and Fiscal Policies to Solve Economic Problems. The Revenue Department Journal, 2000(47), 35-44.

Lopez, H., Fajnzylber, P., Calderon, C., \& Acosta, P. (2007). What is the impact of international remittances on poverty and inequality in Latin America? : The World Bank.

Mitra, R. M. (2013). Leveraging service sector growth in the Philippines.

Monacelli, T., \& Perotti, R. (2010). Fiscal policy, the real exchange rate and traded goods. The Economic Journal, 120(544), 437-461.

Mundell, R. (1963). Inflation and real interest. Journal of political economy, 71(3), 280-283.

Musa, Y., Usman, U., \& Zoramawa, A. B. (2014). Relationship between money supply and Government revenues in Nigeria. CBN Journal of Applied Statistics, 5(2), 117-136.

Nawaz, M. (2012). The impact of exchange rate on output level: bounds testing approach for Pakistan. The Pakistan Development Review, 419-433.

Obstfeld, M., \& Rogoff, K. (1995). Exchange rate dynamics redux. Journal of political economy, 103(3), 624-660.

OECD. (2015). Organization for Economic Cooperation and Development. Retrieved from https://data.oecd.org/

Perotti, R. (2005). Estimating the effects of fiscal policy in OECD countries.

Perotti, R. (2007). Fiscal policy in developing countries: a framework and some questions: The World Bank.

Pindyck, R., \& Rubinfeld, D. (1997). Econometric Models and Economic Forecasts book. In: McGraw-Hill/Irwin.

Pylak, K., \& Majerek, D. (2015). Impact of the service sector on the creation of companies in Poland. Procedia Economics and Finance, 24, 523-532.

Šimáková, J., \& Stavárek, D. (2014). Exchange-Rate Impact on the Industry-Level Trade Flows in the Czech Republic. Procedia Economics and Finance, 12, 679-686.

Singh, R. S. (2014). India's Service Sector-Shaping Future of Indian Retail Industry. Procedia Economics and Finance, 11, 314-322.

Tadele, B. (2013). Analysis of tax buoyancy and its determinants in Ethiopia. Journal of Economics and Sustainable Development, 6(3), 2015.

Van Wijnbergen, S. (1986). Exchange rate management and stabilization policies in developing countries. Journal of Development Economics, 23(2), 227-247.

Verspagen, B. (2000). Growth and structural change: Trends, patterns and policy options.

Wooldridge, J. (1996). Estimating systems of equations with different instruments for different equations. 74(2), 387-405.

Wooldridge, J. (2009). Introductory Econometrics: a modern approach. 4th.

World Bank. (2015a). World development indicators database. Retrieved from https://databank.worldbank.org/source/world-development-indicators

Zellner, A., \& Theil, H. (1962). Three-stage least squares: simultaneous estimation of simultaneous equations. Econometrica: Journal of the Econometric Society, 54-78.

Zhang, K. H. (2001). Does foreign direct investment promote economic growth? Evidence from East Asia and Latin America. Contemporary economic policy, 19(2), 175-185. 